\title{
THE CAUSES OF CONGENITAL CLUB FOOT
}

\author{
BY \\ EVA D. ALBERMAN \\ From the Paediatric Research Unit, Guy's Hospital Medical School, London
}

(RECEIVED FOR PUBLICATION JANUARY 4, 1965)

\begin{abstract}
$\ldots$ 'I devoted much attention to the nature of these distortions, from the circumstance of my being afflicted with Talipes in the left foot.'
\end{abstract}

William Little (1839)

Hippocrates was the first to suggest that permanent crippling can follow abnormal intrauterine pressure. More recently, Browne (1936) has been the foremost exponent of the view that this is a major cause of congenital club feet. The theory had first been challenged in the early 19th century by the authors of several very detailed studies on the condition. Little (1839) felt that the variety of deformities found in club feet could not be accounted for by the pressure theory, or by the theory of arrested foetal development, as suggested by von Walther (1833). Little, like Guérin (1839), considered that as in club foot of postnatal onset, congenital talipes is due to muscle paralysis or spasm. Adams (1873) also inclined towards this 'dynamic' theory, but thought that in some cases, particularly of talipes calcaneous or calcaneovalgus, the origin was mechanical distortion.

All authors acknowledge the strong family history in about one-tenth of patients with foot deformities, and the frequent coexistence of other congenital defects. Ehrenfried (1912) found associated anomalies in $13.4 \%$ of the 232 cases he investigated. Crabbe (1960) in a review of 172 patients with congenital talipes found associated congenital defects in $11.2 \%$. He pointed out that mechanical compression could not account for the significant increase of anomalies such as arachnodactyly, cleft palate, webbing of the toes, and sacral agenesis, which are probably faults in mesenchymal differentiation. Wynne-Davies (1964) has recently reported the results of family studies on 635 patients with club feet, and also concluded that defective formation of connective tissue was an important aetiological factor.

Previous investigations have been carried out on patients attending orthopaedic clinics, so that babies with associated lethal malformations or those with very slight deformities have been excluded. A study of all babies with foot deformities noted in a consecutive series of births gives an estimate of the incidence of each type, together with associated anomalies, and an indication of any predisposing factors in pregnancy.

In the following account, the birth and antenatal records of 170 babies with foot deformities delivered at Queen Charlotte's Maternity Hospital during the years 1958 to 1961 are compared with those of a control series.

\section{Method}

The birth records of 170 babies noted to have foot deformities at birth in Queen Charlotte's Maternity Hospital during the years 1958 to 1961 were studied and relevant details abstracted. Similar details were abstracted from a control series of 170 births immediately preceding them in the labour ward register.

All babies born at this hospital are examined by the obstetric house surgeon and are referred to the paediatrician if any abnormality is found. Classification of the deformities was made on the basis of the description in the records. The patients were placed into the following categories: talipes equinovarus, talipes calcaneovalgus, metatarsus varus, and a fourth class of mixed or other clinical types. Patients with deformities of which the clinical description was not sufficiently detailed to allow classification were included in the latter group. Table 1 gives the numbers in each clinical group.

Among the 170 cases were 3 pairs of sibs born at Queen Charlotte's during the period of the study. Both of one pair suffered from talipes equinovarus, both of the second were described as having 'talipes' and were in the 'other' group, and one of the third pair had metatarsus varus while her sib was in the 'other' group. There were, therefore, 3 less mothers than there were patients with foot deformities, 167 compared with 170 controls. Only one of each of the 5 pairs of twins in the series had been affected. Two had been like sex pairs but in both the placenta was considered to be binovular in type, and it is, therefore, probable that all 5 pairs were dizygotic. 
TABLE 1

NUMBERS OF TWINS AND SINGLETONS IN CLINICAL CATEGORIES

\begin{tabular}{|c|c|c|c|c|c|c|c|c|c|}
\hline \multicolumn{4}{|c|}{ Clinical Category } & $\begin{array}{c}\text { Talipes } \\
\text { Equinovarus }\end{array}$ & $\begin{array}{c}\text { Talipes } \\
\text { Calcaneovalgus }\end{array}$ & $\begin{array}{c}\text { Metatarsus } \\
\text { Varus }\end{array}$ & $\begin{array}{l}\text { Mixed or } \\
\text { Other }\end{array}$ & All & Controls \\
\hline $\begin{array}{l}\text { Singletons } \\
\text { Twins }\end{array}$ & $\begin{array}{l}\cdots \\
\cdots\end{array}$ & $\begin{array}{l}\cdots \\
\cdots\end{array}$ & $\begin{array}{l}\cdots \\
\cdots\end{array}$ & $\begin{array}{r}36 \\
0\end{array}$ & $\begin{array}{r}32 \\
0\end{array}$ & $\begin{array}{r}34 \\
0\end{array}$ & $\begin{array}{r}63 \\
5\end{array}$ & $\begin{array}{r}165 \\
5\end{array}$ & $\begin{array}{r}169 \\
1\end{array}$ \\
\hline All & $\ldots$ & $\ldots$ & $\ldots$ & 36 & 32 & 34 & 68 & 170 & 170 \\
\hline
\end{tabular}

Only information available from the records was considered, and family histories were those obtained as a routine at the booking visit. The length of gestation was calculated from the recorded date of the first day of the last menstrual period.

The tests of significance used were the $\chi^{2}$ test using fourfold tables and Yates' correction, the difference between proportions, and Student's ' $t$ ' test for the difference between means. A $5 \%$ level of probability or less was accepted as statistically significant.

\section{Results}

The Incidence of Foot Deformities. The 170 babies in this study were derived from 12,048 births which included 466 stillbirths and neonatal deaths. This gave an incidence of $14 \cdot 1$ babies recorded as having foot deformities in 1,000 births. The incidence of each clinical type is given in Table 2.

TABLE 2

INCIDENCE OF CLINICAL TYPES IN TOTAL BIRTHS

\begin{tabular}{|c|c|c|c|}
\hline \multicolumn{3}{|c|}{ Clinical Type } & $\begin{array}{l}\text { Incidence per Thousand } \\
\text { Total Births } \\
\text { (Nos. in brackets) }\end{array}$ \\
\hline $\begin{array}{l}\text { Talipes equinovarus } \\
\text { Talipes calcaneovalgus } \\
\text { Metatarsus varus } ; \text { ' } \\
\text { Mixed and 'others' }\end{array}$ & $\begin{array}{l}\cdots \\
\cdots \\
\cdots\end{array}$ & $\begin{array}{l}\cdots \\
\cdots \\
\cdots\end{array}$ & $\begin{array}{l}3 \cdot 0(36) \\
2 \cdot 7(32) \\
2 \cdot 8(34) \\
5 \cdot 6(68)\end{array}$ \\
\hline All .. & .. & .. & $14 \cdot 1(170)$ \\
\hline
\end{tabular}

The Mothers. The mothers of the cases were recorded as having slightly, though not significantly, more congenital malformations. Four mothers had had operations for congenital malformations. One who had bunions and flat feet had undergone surgery at the age of 11 years, two others had had a congenital dislocation of the hips, and the fourth had had torticollis. No record of any foot deformity was found in these last three patients. Antepartum diagnosis of uterine malformations was slightly more common amongst the mothers of the affected babies, but the excess was not significant.

No significant difference was found between the mean maternal age of the propositi and that of the controls. Although the proportion of primiparae amongst the mothers of the propositi was consistently higher than that in the controls, this excess was significant only in the group with talipes calcaneovalgus, in which three-quarters of the babies had been firstborn compared with just over one-half of the controls $(\mathrm{p}<0.05)$.

These findings are set out in detail in Table 3.

Pregnancy and Delivery. Table 4 gives some details of the pregnancies and deliveries of the cases and controls. There were few differences between these, the only difference of statistical significance being the longer mean period of gestation of babies

TABLE 3

MEAN MATERNAL AGE, PRIMIPARITY, AND CONGENITAL DEFECTS OF THE MOTHERS

\begin{tabular}{|c|c|c|c|c|c|}
\hline & $\begin{array}{c}\text { Talipes } \\
\text { Equinovarus }\end{array}$ & $\begin{array}{c}\text { Talipes } \\
\text { Calcaneovalgus }\end{array}$ & $\begin{array}{l}\text { Metatarsus } \\
\text { Varus }\end{array}$ & $\begin{array}{l}\text { Mixed or } \\
\text { 'Other' }\end{array}$ & Controls \\
\hline $\begin{array}{c}\text { Mean maternal age (yr.) (No. } \\
\text { known in brackets) .. }\end{array}$ & $27 \cdot 2(35)$ & $26 \cdot 8(32)$ & $27 \cdot 2(34)$ & $26 \cdot 6(68)$ & $26 \cdot 2(170)$ \\
\hline Per cent. primiparae .. & $61 \cdot 1$ & $75 \cdot 0$ & $55 \cdot 9$ & $57 \cdot 3$ & $51 \cdot 8$ \\
\hline \multirow[t]{5}{*}{ Congenital malformations } & $\begin{array}{l}\text { Flat feet and } \\
\text { bunions at } \\
11 \text { years }\end{array}$ & $\begin{array}{l}\text { Congenital } \\
\text { dislocation } \\
\text { of hips- }\end{array}$ & $\begin{array}{l}\text { Congenital } \\
\text { pulmonary } \\
\text { stenosis }\end{array}$ & $\begin{array}{l}\text { Dysplasia of } \\
\text { the hip- } \\
\text { 'shelf' operation }\end{array}$ & Bunions \\
\hline & $\begin{array}{l}\text { Bicornuate } \\
\text { uterus }\end{array}$ & artinuesis & Arcuate uterus & Torticollis & Spondylolisthesis \\
\hline & & & & $\begin{array}{l}\text { Double vagina } \\
\text { and uterus }\end{array}$ & Cleft palate \\
\hline & & & & & $\begin{array}{l}\text { Uterus arcufor- } \\
\text { mis } \\
\text { ?? Bicornuate } \\
\text { uterus }\end{array}$ \\
\hline & $\begin{array}{l}2 \text { in } 35 \text { mothers } \\
5.7 \%\end{array}$ & $\begin{array}{l}1 \text { in } 32 \text { mothers } \\
3.1 \%\end{array}$ & $\begin{array}{l}2 \text { in } 34 \text { mothers } \\
5.9 \%\end{array}$ & $\begin{array}{l}3 \text { in } 67 \text { mothers } \\
4.5 \%\end{array}$ & $\begin{array}{l}5 \text { in } 170 \text { mothers } \\
2.9 \%\end{array}$ \\
\hline
\end{tabular}


TABLE 4

PREGNANCY AND DELIVERY

\begin{tabular}{|c|c|c|c|c|c|c|c|c|c|c|c|c|}
\hline & \multicolumn{4}{|c|}{ Talipes Equinovarus } & \multirow{2}{*}{\multicolumn{2}{|c|}{$\begin{array}{c}\text { Talipes } \\
\text { Calcaneovalgus } \\
(32)\end{array}$}} & \multirow{2}{*}{\multicolumn{2}{|c|}{$\begin{array}{l}\text { Metatarsus } \\
\text { Varus (34) }\end{array}$}} & \multirow{2}{*}{\multicolumn{2}{|c|}{ Others (68) }} & \multirow{2}{*}{\multicolumn{2}{|c|}{ Controls (170) }} \\
\hline & \multicolumn{2}{|c|}{$\begin{array}{c}\text { With } \\
\text { Associated } \\
\text { Defect }(12)^{*}\end{array}$} & \multicolumn{2}{|c|}{$\begin{array}{c}\text { Without } \\
\text { Associated } \\
\text { Defect (24)* }\end{array}$} & & & & & & & & \\
\hline & No. & $\%$ & No. & $\%$ & No. & $\%$ & No. & $\%$ & No. & $\%$ & No. & $o_{0}$ \\
\hline $\begin{array}{l}\text { Attempted version (failed } \\
\begin{array}{l}\text { and successful) } \\
\text { Breech delivery }\end{array} \\
\text { Caesarean section }\end{array}$ & $\begin{array}{l}2 \\
4 \\
0\end{array}$ & $\begin{array}{r}(17) \\
(33) \\
(0)\end{array}$ & $\begin{array}{l}2 \\
0 \\
0\end{array}$ & $\begin{array}{l}(8) \\
(0) \\
(0)\end{array}$ & $\begin{array}{l}2 \\
1 \\
0\end{array}$ & $\begin{array}{l}6 \\
3 \\
0\end{array}$ & $\begin{array}{l}0 \\
0 \\
4\end{array}$ & $\begin{array}{r}0 \\
0 \\
12\end{array}$ & $\begin{array}{l}7 \\
3 \\
4\end{array}$ & $\begin{array}{r}10 \\
4 \\
6\end{array}$ & $\begin{array}{r}29 \\
5 \\
9\end{array}$ & $\begin{array}{r}17 \\
3 \\
5\end{array}$ \\
\hline $\begin{array}{c}\text { Mean length of gestation } \\
\text { (wk.) } \ldots\end{array}$ & \multicolumn{2}{|c|}{$\begin{array}{c}39 \cdot 5 \\
\text { (2 unknown) }\end{array}$} & \multicolumn{2}{|c|}{$\begin{array}{c}39 \cdot 1 \\
(4 \text { unknown) }\end{array}$} & \multicolumn{2}{|c|}{$\begin{array}{c}39 \cdot 7 \\
(2 \text { unknown) }\end{array}$} & \multicolumn{2}{|c|}{$\begin{array}{c}40 \cdot 9 \\
(2 \text { unknown) }\end{array}$} & \multicolumn{2}{|c|}{$\begin{array}{c}40 \cdot 0 \\
(4 \text { unknown) }\end{array}$} & \multicolumn{2}{|c|}{$\begin{array}{c}39 \cdot 8 \\
\text { (11 unknown) }\end{array}$} \\
\hline
\end{tabular}

* Where there are fewer than 30 cases the percentages are given in parentheses.

TABLE 5

PROPORTION OF BOYS AND MEAN BIRTH WEIGHT OF BABIES

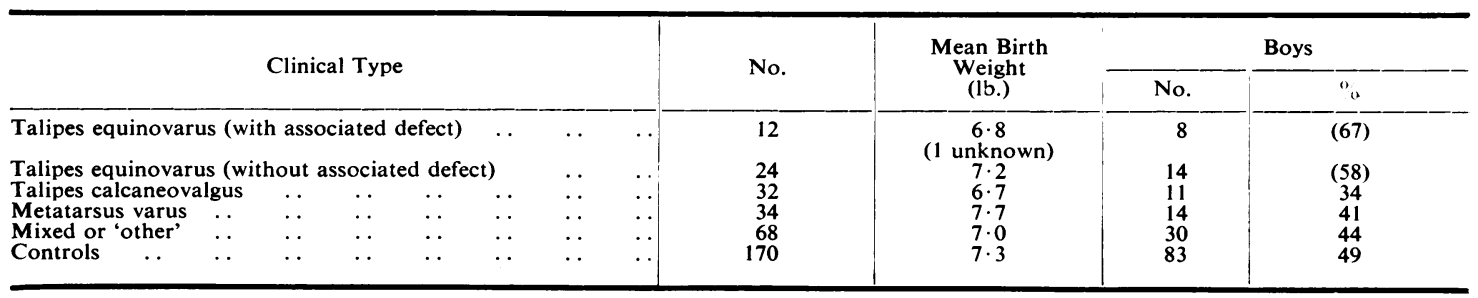

Where there are fewer than 30 cases the percentages are given in parentheses.

with metatarsus varus, over a week longer than that of the controls $(p<0.05)$. Also in this group more than 1 in 10 babies were delivered by caesarean section, twice as many as in the controls, but this difference is not statistically significant. The proportion of breech delivery among babies with foot deformities was slightly, but again not significantly, higher than among the controls.

The Babies. In Table 5 are set out the mean birth weights and the proportion of boys in the cases and the controls.

An excess of boys was found among all babies with talipes equinovarus, in the proportion of 1.6 to 1. In contrast, an excess of girls was found in the other types of foot deformities, most marked among the babies with talipes calcaneovalgus, in whom the proportion was 1.9 to 1 .

The mean birth weight of most groups of babies with foot deformities was very similar to that of the controls, when allowance was made for length of gestation, birth order, and sex ratio. The one exception was the group of babies with talipes equinovarus associated with other malformations, in which the mean birth weight was lower than that of controls of similar gestational age.

More associated defects were reported in the babies with foot deformities than might have been expected in comparison with the controls. In the latter, a congenital defect was noted in 16 out of 170 babies $(9 \cdot 4 \%)$. Defects other than those of the feet were noted in $12(33 \%)$ of the talipes equinovarus group, $7(22 \%)$ of the talipes calcaneovalgus group, $8(24 \%)$ of the metatarsus varus group, and 8 $(12 \%)$ of the remaining babies with foot deformities. The defects are listed in Table 6.

Congenital Defects in Older Sibs. In all, the control babies had a total of 140 older sibs. Of these, $5(3.6 \%)$ were known to have had severe congenital malformations (Table 7). The babies with talipes equinovarus had 30 older sibs and 4 $(13 \cdot 3 \%)$ had had severe malformations, significantly more than in the controls $(p<0.05)$. In order to determine whether a history of malformations in older sibs was confined to propositi who themselves had malformations other than of the feet, the group of talipes equinovarus patients was divided into those in whom this was the sole apparent defect, and those in whom it was associated with any other malformation. The 12 propositi with associated defects had only 3 older sibs between them, and of these one had died with hydrocephalus and spina bifida. The remaining 24 without associated defects had 27 older sibs; of these 2 had died with central nervous system malformations, and one had 
TABLE 6

ASSOCIATED ANOMALIES

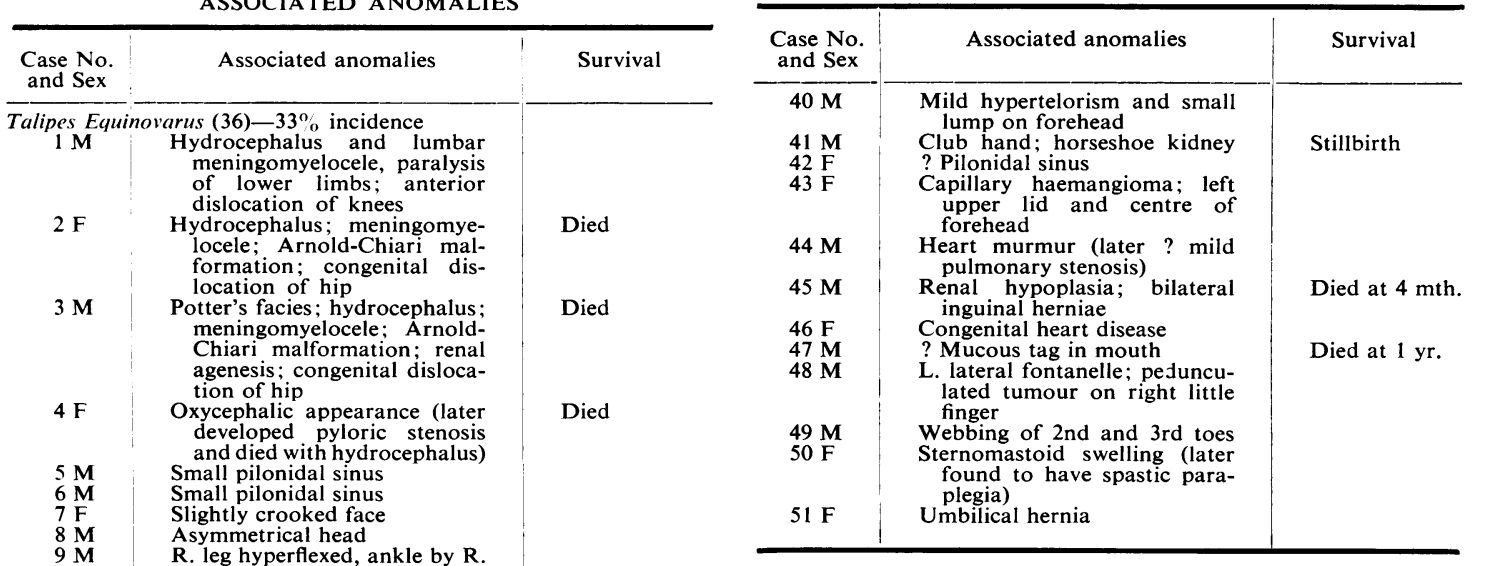

ear; cauliflower ears; con-

Tibial recurvatae; four toes on each foot

$11 \mathrm{~F}$ Marked capillary naevus on

Marked

$12 \mathrm{M} \quad \begin{gathered}\text { forehead } \\ \text { Umbilical hernia }\end{gathered}$

Talipes Calcaneovalgus (32) $-22 \%$ incidence

$13 \mathrm{~F}$ Suspicion of pilonidal sinus

$14 \mathrm{~F}$ Asymmetrical head; small occi-

pital lump

15 F Asymmetrical face: nose to

left, jaw to right. ? 3rd left, jaw to right. ? 3rd

$16 \mathrm{M}$ Compression-left ear applied to left shoulder

$17 \mathrm{M}$ Branchial cleft sinus

$18 \mathrm{~F}$ Vascular naevus of abdomen

$19 \mathrm{M}$ Abnormal nose, ears, eyes; limited knee extension; short microphallus; atresia or coarctation of aorta; cor biloculare; diaphragmatic hernia, pulmonary hypoplasia

Metatarsus Varus (34)-24\% incidence

$20 \mathrm{~F}$ Two accessory nipples right ear

$21 \mathrm{M} \quad$ Hypospadias; accessory auricle right ear

$22 \mathrm{~F} \quad$ Accessory auricle left ear

$23 \mathbf{M}$ Pilonidal sinus; small penis

$24 \mathrm{~F}$ 'Mongoloid but not mongol'

$25 \mathrm{M}$ Congenital heart defect

$26 \mathrm{M}$ Bulging right parietal region

$27 \mathrm{~F}$ Umbilical hernia

Mixed or Others (68)-12\% incidence

$28 \mathrm{M}$ Deep sacrococcygeal pit

$29 \mathrm{M}$ Bilateral aural tags

$30 \mathrm{~F}$ Torticollis

$31 \mathrm{~F}$ Torticollis

$32 \mathrm{M}$ Dysplasia of hip (familial); mild hypospadias

$33 \mathrm{~F}$ : Bilateral simple cataract

$34 \mathrm{M}$ Abnormality of whole of right leg and pelvis; inguinal hernia (later

Exomphalos; cleft palate and lip; malrotation of heart stenosis of pelvi-ureteral junction

Controls (170)-9.4\% incidence

$36 \mathrm{~F}$ Capillary naevus upper lip, and tip and bridge of nose

$\begin{array}{ll}37 \mathbf{M} & \text { Accessory auricle of ear } \\ 38 \mathrm{~F} & \text { All joints lax; small angioma }\end{array}$

$38 \mathrm{~F}$
$39 \mathrm{M}$ sutures congenital heart disease. This proportion with malformations, 3 in $27(11 \%)$, was over three times as large as that in the control group, though the difference no longer reached the $5 \%$ level of significance.

There were 2 patients of particular interest in the group. One mother who had a bicornuate uterus had first a stillbirth with iniencephaly and then a baby with apparently uncomplicated talipes equinovarus. A second mother, who had had a myomectomy for the removal of 25 fibroids and had many remaining fibroids, had borne a child with talipes equinovarus who had died with hydrocephalus, followed by a baby with apparently uncomplicated talipes equinovarus.

No congenital malformations had been reported amongst the older sibs of babies with metatarsus varus or talipes calcaneovalgus, but in the remaining group of mixed and 'other' cases, 5 out of 51 previous sibs $(9.8 \%)$ had had foot deformities. No foot deformities had been recorded among older sibs of the controls.

\section{Discussion}

Incidence. The incidence of foot deformities in this series of hospital births was $14 \cdot 1$ per 1,000 total births. This is a little higher than the incidence reported in a recent series of hospital births (Marden, Smith, and McDonald, 1964), in which the incidence of equinovarus, severe calcaneovalgus, and severe metatarsus adductus deformities together was $8 \cdot 2$

Stillbirth per 1,000. However, the latter series did not include any stillbirths, and it is likely that the present series includes more mild deformities.

In the present series there were 5 times as many twins among the affected babies as among the controls. While this difference was not statistically significant, this slight excess was similar to that
TABLE 6 (continued) 
TABLE 7

MALFORMATIONS IN OLDER SIBS

\begin{tabular}{|c|c|c|c|c|c|}
\hline & Talipes Equinovarus & $\begin{array}{l}\text { Talipes } \\
\text { Calcaneo- } \\
\text { valgus }\end{array}$ & $\begin{array}{l}\text { Metatarsus } \\
\text { Varus }\end{array}$ & Mixed or 'Other' & Controls \\
\hline No. of all older sibs & 30 & 20 & 23 & 51 & 140 \\
\hline $\begin{array}{l}\text { Congenital malformations } \\
\text { recorded }\end{array}$ & $\begin{array}{l}\text { Hydrocephalus and } \\
\text { spina bifida } \\
\text { * ? Hydrocephalus; } \\
\text { talipes (died) } \\
\text { Iniencephaly } \\
\text { Congenital heart } \\
\text { disease }\end{array}$ & - & - & $\begin{array}{r}* \text { Talipes } \\
* \text { Talipes } \\
\text { Talipes } \\
\text { Talipes } \\
\text { Talipes }\end{array}$ & $\begin{array}{l}\text { Anencephaly and spina } \\
\text { bifida } \\
\text { Anencephaly } \\
\text { Achondroplasia } \\
\text { 'Progressive spinal } \\
\text { atrophy' } \\
\text { 'Congenital } \\
\text { malformation'; ? type }\end{array}$ \\
\hline Total incidence $(\%) \quad \ldots \quad \ldots$ & $13 \cdot 3$ & 一 & - & $9 \cdot 8$ & $3 \cdot 6$ \\
\hline
\end{tabular}

found by Ehrenfried (1912) in a series of patients with a foot deformity.

Clinical Types. It is clear that the term congenital club foot comprises a heterogeneous group of conditions. There are three main clinical types: talipes equinovarus, talipes calcaneovalgus, and metatarsus varus. Within these are several subgroups with differing clinical associations and, apparently, of different aetiology. The findings in the three main groups will be discussed separately.

Talipes Equinovarus. Malformations of the central nervous system are the major deformity in many babies with equinovarus, and in these it seems probable that the foot deformity is caused by a defect in the nerve supply to the lower limbs. In the present series an overt neurological malformation was found in 4 out of 36 babies born with talipes equinovarus. In 2 further patients with apparently uncomplicated talipes equinovarus, the history of a previous sib with a lethal malformation of the central nervous system was also suggestive of a neurological basis for the foot deformity.

Although there were no examples in this series, it is clear from the published material that congenital club foot may be associated with neurological defects other than hydrocephalus and spina bifida. It has been described in association with spastic diplegia (Ingram, 1964), with bulbar palsy (Graham, 1964), and Möbius' syndrome (congenital facial diplegia) (Evans, 1955). However, Evans suggested that in Möbius' syndrome the defect may be a congenital deficiency of the muscles rather than nuclear agenesis. Talipes equinovarus has also been described in association with undoubted skeletal or muscular defects. Case 10 (Table 6) is an example of an equinovarus deformity associated with tibiae recurvatae and 4 toes on each foot. There is also a well-recognized association between talipes and arthrogryposis.

Wynne-Davies (1964) in a painstaking survey of 163 patients with talipes equinovarus and their relatives found that there was an excess of associated malformations which could be attributable to a hereditary defect of connective tissue. A significant excess of the patients she examined had a generalized joint laxity, and she suggested that this laxity had increased the susceptibility of the foetus to intrauterine forces. In the present series also, the finding that at least two mothers of babies with equinovarus had uterine malformations suggested that intrauterine pressure had played some part in causing the deformity.

Equinovarus deformities of the feet, often together with facial malformations, have been described in cases of oligohydramnios, both in those with renal agenesis (Potter, 1961) and in those secondary to other causes (Bain, Smith, and Gauld, 1964). In this series, Case 9 with talipes equinovarus (Table 6), in which there had been a 7-week history of ruptured membranes, is an example of such an association. No entirely satisfactory explanation of the mechanism of the foetal deformation has yet been put forward, though it is usually attributed to 'uterine pressure' (Bain et al., 1964). Drachman and Coulombre (1962) found that experimental immobilization of chick embryos was followed by the development of limb deformities and suggested that immobilization might also cause joint deformities in the human foetus.

In this, as in all previous series, boys with talipes equinovarus have exceeded girls in the ratio of about 2 to 1 (Little, 1839; Adams, 1873; Wynne-Davies, 1964). Moreover, Wynne-Davies found that male relatives of female patients are at particular risk. This apparent male susceptibility to equinovarus is intriguing in view of the high incidence of talipes 
equinovarus reported in patients found to have an XYY sex chromosome constitution. In 11 patients with this constitution, selected for study because of mental, genital, or familial defects, 2 were said to have talipes equinovarus (K. E. Buckton, J. A. Bond, and J. A. McBridge, 1962, personal communication; Castilla and Breg, 1963; Court Brown, Harnden, Jacobs, Maclean, and Mantle, 1964; Fraccaro, Davies, Glen Bott, and Schutt, 1962; Hustinx and Val Olphen, 1963; St. M. Milcu, I. Negoescu, M. Garoiu, I. Iliescu, M. Augustin, and C. Maximilian, 1963, personal communication; Ricci and Malacarne, 1964; Sandberg, Ishihara, Crosswhite, and Koepf, 1963; Vignetti, Capotorti, and Ferrante, 1964). In a further unpublished case (Paediatric Research Unit, H2599/359) bilateral calcaneovarus and flexion deformities of the knees were found. In patients with XXYY constitution a high proportion of skeletal malformations has also been described (Robinson, Miller, Dill, and Kamburoff, 1964), including 2 with talipes equinovarus (Barr, Carr, Soltan, Wiens, and Plunkett, 1964; Muldal, Ockey, Thompson, and White, 1962). It is noteworthy that the presence of a $\mathrm{Y}$ chromosome appears to increase the risk of specifically a varus deformity, while, it will be shown below, females are more likely to develop a valgus deformity.

Talipes Calcaneovalgus. Features of the group with talipes calcaneovalgus in this series were an excess of girls and an excess of firstborn children, findings similar to those described by Wynne-Davies (1964). Her suggestion that there was an aetiological connexion between this condition and congenital dislocation of the hip was borne out by the finding that in two babies in this series, one with calcaneovalgus and the other with a 'valgus' deformity, the mothers had suffered from congenital dislocation of the hips.

Wynne-Davies found that among patients with talipes calcaneovalgus, as among those with equinovarus, there was an excessive number with generalized joint laxity. Carter and Wilkinson (1964) suggested that in congenital dislocation of the hips an adverse uterine posture superimposed on a generalized joint laxity and a shallow acetabulum could cause the dislocation. They considered that generalized joint laxity was either familial or a temporary hormonalinduced condition in newborn girls. This hormonalinduced laxity could account for the excess of girls with congenital dislocation of the hip. It seems possible that analogous factors predispose to talipes calcaneovalgus; a combination of unduly lax ligaments, slightly abnormal articular surfaces, and unusual uterine forces. Wynne-Davies suggested that the tight abdominal musculature found in primiparae may explain the apparent increase in risk to firstborn children.

However, in the group of calcaneovalgus, as in equinovarus, there is evidence for the existence of at least one aetiological sub-group. Calcaneovalgus feet have been described in 10 out of 23 babies with $E_{1}$ trisomy (Polani, 1964), and the clinical features of one patient in the present series (Case 19, Table 6) would be consistent with such a diagnosis. Polani found that in this condition hypertonus was often present and hydramnios was common, features that seem to rule out the possibility that intrauterine pressure played a part in causing the deformity. Moreover, he noted that in all 12 cases in which the hips had been examined, abduction had been limited, and in two they had been dislocated. Two-thirds of the cases of $E_{1}$ trisomy had been girls. The similarity of these features to those in the uncomplicated cases of talipes calcaneovalgus provoke further speculation about the aetiology of the condition, but as yet the connexion between the deformity and abnormalities of the chromosomes is obscure.

Metatarsus Varus. In the group of patients with metatarsus varus the high incidence of associated malformations, including congenital heart disease, hypospadias, and aural tags, suggested a defect arising early in foetal development. Nevertheless in this group there is a raised incidence of postmaturity, a condition in which a decrease in liquor amnii is said to occur (Walker, 1954), again a hint that mechanical distortion in utero may play some part in causing the condition.

\section{Conclusions}

The findings in the present study, as in that by Wynne-Davies (1964), confirm the complexity of factors that interact to produce congenital deformities of the feet. Methods that will help unravel the aetiology of these conditions are further intensive family studies of patients with different clinical types, and the study of more generalized congenital defects in which the foot deformity may be subsidiary to other malformations.

\section{Summary}

Among babies born in Queen Charlotte's Maternity Hospital during the years 1958 to 1961 , there were 170 with foot deformities, an incidence of $14 \cdot 1$ per 1,000 total births.

A study of birth histories suggested that in many of the babies the deformity had resulted from the interaction of abnormal environmental and heredi- 
tary factors. However, the predisposing causes in the different clinical types appeared to differ. Associated neurological malformations were often found in babies with talipes equinovarus, and a family history of central nervous system malformations was unduly common. No such associations were found in babies with talipes calcaneovalgus, but there were indications that the condition was related in some way to congenital dislocation of the hips.

The apparent susceptibility of males to talipes equinovarus and females to talipes calcaneovalgus is discussed in the light of their reported association with anomalies of chromosome constitution.

I am most grateful to the Board of Governors of Queen Charlotte's Hospital, and Dr. White Franklin and Dr. Norman for allowing me to study their cases. I am also indebted to Miss Terry, the Records' Officer, for her help, Professor Polani for many helpful suggestions, and to the Cytogenetic Staff of the Paediatric Research Unit for the chromosome analysis of Case H2599/359.

The work was supported by the Spastics Society.

\section{REFERENCES}

Adams, W. (1873). Club Foot. Its Causes, Pathology and Treatment, p. 217. Churchill, London.

Bain, A. D., Smith, I. I., and Gauld, I. K. (1964). Newborn after prolonged leakage of liquor amnii. Brit. med. J., 2, 598.

Barr, M. L., Carr, D. H., Soltan, H. C., Wiens, R. G., and Plunkett E. R. (1964). The XXYY variant of Klinefelter's syndrome. Canad. med. Ass. J., 90, 575.

Browne, D. (1936). Congenital deformities of mechanical origin. Proc. roy. Soc. Med., 29, 1409.

Carter, C., and Wilkinson, J. (1964). Persistent joint laxity and congenital dislocation of the hip. J. Bone Jt Surg., 46-B, 40.

Castilla, E. E., and Breg, W. R. (1963). The XYY sex chromosome constitution. The National Foundation Mammalian Cytogenetics Conference, Sept. 26-28, 11.

Court Brown, W. M., Harnden, D. G., Jacobs, P. A., Maclean, N., and Mantle, D. J. (1964). Abnormalities of the sex chromosome complement in man. Spec. Rep. Ser. med. Res. Coun. (Lond.), $305,107$.

Crabbe, W. A. (1960). Aetiology of congenital talipes. Brit. med.J., 2, 1060 .

Drachman, D. B., and Coulombre. A. J. (1962). Experimental clubfoot and arthrogryposis multiplex congenita. Lancet, 2, 523.

Ehrenfried, A. (1912). The occurrence and etiology of club-foot. J. Amer. med Ass., 59, 1940.

Evans, P. R. (1955). Nuclear agenesis. Möbius' syndrome: the congenital facial diplegia syndrome. Arch. Dis. Childh., 30, 237.

Fraccaro. M., Davies, P., Glen Bott, M., and Schutt, W. (1962). Mental deficiency and undescended testis in two males with XYY sex chromosomes. Folia hered. path. (Milano), 11, 211.

Graham, P. J. (1964). Congenital flaccid bulbar palsy. Brit. med. J., 2. 26.

Guérin, J. (1839). Mémoire sur les Variétés Anatomiques du Pied-bot Congénital. Cinquième Mémoire sur les Difformités du Système Osseux. Au Bureau de la Gazette Medicale, Paris.

Hustinx, T. W. J., and Val Olphen, A. H F. (1963). An XYY chromosome pattern in a boy with Marfan's syndrome. Genetica, 34, 262.

Ingram, T. T. S. (1964). Paediatric Aspects of Cerebral Palsy, p. 243. E. \& S. Livingstone, Edinburgh and London.

Little, W. J. (1839). A Treatise on the Nature of Clubfoot and Analogous Distortions, pp. xli \& 23. W. Jeffs, London.

Marden, P. M., Smith, D. W., and McDonald, M. J. (1964) Congenital anomalies in the newborn infant, including minor variations. J. Pediat., 64, 357.

Muldal, S., Ockey, C. H., Thompson, M., and White, L. L. R. (1962). "Double male"-a new chromosome constitution in the Klinefelter syndrome. Acta endocr. (Kbh.), 39, 183.

Polani, P. E. (1964). Chromosome anomalies. Ann. Rev. Med., 15, 93.

Potter, E. L. (1961). Pathology of the Fetus and the Infant. Year Book Medical Publishers, Chicago.

Ricci, N., and Malacarne, P. (1964). An XYY human male. Lancet, 1, 721.

Robinson, G. C., Miller, J. R., Dill, F. J., and Kamburoff, T. D. (1964). Klinefelter's syndrome with the XXYY sex chromosome complex. J. Pediat., 65, 226.

Sandberg, A. A., Ishihara, T., Crosswhite, L. H., and Koepf, G. F. (1963). XYY genotype: report of a case in a male. New Engl. J. Med., 268, 585.

Vignetti, P., Capotorti, L., and Ferrante, E. (1964). XYY chromosomal constitution with genital abnormality. Lancet, 2, 588.

Walker, J. (1954). Foetal anoxia. J. Obstet. Gynaec. Brit. Emp., 61. 162.

Walther, P. F. von (1833). System der Chirurgie, vol. 1, p. 344. G. Reimer, Berlin. (Cited by Little, 1839, p. xli.)

Wynne-Davies, R. (1964). Family studies and the cause of congenital club foot. J. Bone Jt Surg., 46-B, 445. 